\title{
Neurotoxicity and aggressiveness triggered by low-level lead in children: a review
}

\author{
Kelly Polido Kaneshiro Olympio, ${ }^{1}$ Claudia Gonçalves, ${ }^{2}$ \\ Wanda Maria Risso Günther, ${ }^{1}$ and Etelvino José Henriques Bechara ${ }^{3}$
}

Suggested citation Olympio KPK, Gonçalves C, Günther WMR, Bechara EJH. Neurotoxicity and aggressiveness triggered by low-level lead in children: a review. Pan Am J Public Health. 2009;26(3):266-75.

\begin{abstract}
Lead-induced neurotoxicity acquired by low-level long-term exposure has special relevance for children. A plethora of recent reports has demonstrated a direct link between low-level lead exposure and deficits in the neurobehavioral-cognitive performance manifested from childhood through adolescence. In many studies, aggressiveness and delinquency have also been suggested as symptoms of lead poisoning. Several environmental, occupational and domestic sources of contaminant lead and consequent health risks are largely identified and understood, but the occurrences of lead poisoning remain numerous. There is an urgent need for public health policies to prevent lead poisoning so as to reduce individual and societal damages and losses. In this paper we describe unsuspected sources of contaminant lead, discuss the economic losses and urban violence possibly associated with lead contamination and review the molecular basis of lead-induced neurotoxicity, emphasizing its effects on the social behavior, delinquency and IQ of children and adolescents.
\end{abstract}

Key words Lead poisoning; neurotoxicity syndromes; oxidative stress; juvenile delinquency.

Since ancient times, lead $(\mathrm{Pb})$ has been known to be toxic to human health (1). Indeed, lead is now recognized as a devastating neurotoxin. The widespread contamination of the environment by lead, the wide range of toxic effects associated with this metal, and the millions of people affected worldwide, both in poor and developed nations, make this insidious and ubiquitous neurotoxicant

1 Universidade de São Paulo, Faculdade de Saúde Pública, Departamento de Saúde Ambiental, São Paulo, SP, Brazil. Send correspondence to: Kelly Polido Kaneshiro Olympio, Marcondes Salgado 1771, bl. 13, apto. 24 - Vl, CEP 17013-231, Antártica, Bauru, SP, Brazil. Tel: +55-14-3879.6884; e-mail: kellypko@usp.br

2 Centro de Extensão Universitária, São Paulo, SP, Brazil.

3 Universidade de São Paulo, Instituto de Química, Departamento de Bioquímica, São Paulo, SP, Brazil, and Universidade Federal de São Paulo, Departamento de Ciências Exatas e da Terra, São Paulo, SP, Brazil. a public health problem of global magnitude and concern (2).

The levels of lead considered tolerable for children have been repeatedly lowered over the last three decades (3-5). In the early 1960s, the toxic threshold was established as venous blood lead levels (BLL) of $60 \mu \mathrm{g} / \mathrm{dL}$, at which overt physical symptoms were observed (6). In 1970, after the recognition that even lower blood lead could cause brain damage (7), the threshold was reduced to $40 \mu \mathrm{g} / \mathrm{dL}$; it was then reduced to $30 \mu \mathrm{g} / \mathrm{dL}$ in 1975 , and to $25 \mu \mathrm{g} / \mathrm{dL}$ in 1985. Finally, in 1991, the Centers for Disease Control and Prevention (CDC) set the intervention level at $10 \mu \mathrm{g} / \mathrm{dL}$. According to Bellinger (8), although this level only intends to serve as a risk guidance and management tool, it has been widely and incorrectly imbued with biological significance for the individual child. Indeed, the intervention level is often interpreted as a threshold, so that a level lower than $10 \mu \mathrm{g} / \mathrm{dL}$ would be "safe," and a higher level would be "toxic." There is not a safe level of lead exposure because factors such as the endpoint of interest, the age at exposure and at assessment, the duration of blood lead elevation, and characteristics of the child's rearing environment must also be considered (8). Recently, studies by Lanphear et al. (9) and Canfield et al. (10) have shown intellectual impairment in children with blood lead concentrations below $10 \mathrm{mg} / \mathrm{dL}$, and Chiodo et al. (11) have demonstrated child neurobehavioral deficits linked to $3 \mu \mathrm{g} / \mathrm{dL}$ concentrations.

The goal of the present study was to discuss unexpected sources of contaminant lead and review the molecular basis of the neurotoxicity induced in children by low-level lead, emphasizing its effects 
on social behavior, criminality and IQ. Finally, we discuss the urgent need for public health policies designed to prevent lead poisoning.

\section{LEAD TOXICITY: A SHORT HISTORY}

According to Needleman (5), childhood lead poisoning was first recognized only one century ago. The author divides scientific knowledge on lead poisoning into four periods. First, there was widespread disbelief concerning reports of lead-poisoned children in Brisbane (Australia), in 1892 (12). In 1904, it was established that the contamination had been caused by lead-containing paint. Lead paint was later banned for household use in Brisbane (5). Today, paints in the United States, for example, cannot contain more than $0.06 \%$ of lead in their formulation (13).

The first report of infantile lead poisoning in the United States was presented by Blackfan (12) in 1914 (5). In this second period in the lead poisoning history, lead was associated with only two outcomes: death or complete recovery without any sequelae. This misconception was refuted in 1943 with the first follow-up of children who had recovered from acute toxicity. Levinson and Harris (14) had previously recommended that children should perhaps be followed on a long-term basis to ascertain possible neurobehavioral disturbances. In 1943, lead poisoning sequelae were well documented by Byers and Lord, who followed 20 children with symptomatic lead poisoning in early childhood until school age. They found that 19 of these children presented aggressive, antisocial, and uncontrollable behavior (15). Thus, in this third period, it became generally accepted that lead toxicity caused long-term neurological impairment, although deficit was thought to occur only in children with clinical signs of encephalopathy during the acute episode. The fourth period began in the 1970s, when studies of children with no clinical signs of toxicity showed deficits in IQ scores, attention, and language (16-18).

\section{MAJOR SOURCES OF LEAD EXPOSURE}

Lead occurs naturally in the lithosphere at concentrations of about $13 \mathrm{mg} / \mathrm{kg}$. Lead was employed to manufacture tableware, trays and other decorative objects as early as $6000 \mathrm{BC}$. The Romans believed that lead-the "oldest" metal-was a gift from Saturn (Khronos), the father of gods. They used lead to build aqueducts and to prepare lead acetate, a sweetener of wine consumed daily by Roman aristocrats. The name saturnism for lead poisoning was coined after Saturn.

In addition, lead occurs naturally in the air, water, soil, biota and in human beings. Human exposure to lead occurs through inhalation, ingestion and through the skin. Lead may be ingested directly from contaminated water, air, and soil and indirectly by eating contaminated animal meat, fruit and vegetables and their derivates. Environmental or occupational exposure may be aggravated by insufficient protective behaviors, habits, and socio-economic factors. Lead is found in food, batteries, solders, plastics, household paints and gas, but also in glass nursing-bottles, toys, glazed pottery, granite floors, calcium supplements, herbal medicines, wild game, facial makeup and cigars. Lead affects the brain, kidneys, liver, blood and testicles and impairs learning, attention, IQ, memory, hearing, and sociability. It causes hypertension, anemia, nephropathies, sterility and encephalopathy, with the degree of poisoning being dependent on blood levels (Figure 1). Human use of lead increased during the Industrial Revolution and in the early 20th century, when there was high demand for leaded gasoline, lead-containing paints, canned foods, and car batteries. Importantly, the population of American children with
BLL over $10 \mu \mathrm{g} / \mathrm{dL}$ declined by $80 \%$ since lead was banned from gas, solder in canned food, and house paint (19). The World Health Organization (WHO) recommends constant research on the various "silent" sources of lead exposure (20). Vigilance is crucial and must be fostered by raising community awareness. Also, there must be strict control of products suspected to contain lead and of imported goods (21).

According to Goyer (22), the most common source of exposure to leadcontaminated food is lead-soldered cans. Outlawing lead solder in canned food is estimated to have reduced the average dietary intake of lead in 2-year-old children from $30 \mu \mathrm{g} /$ day in 1982 to approximately $2 \mu \mathrm{g} /$ day in 1991 (22-24). While banned in the United States, lead solder continues to be used in other countries $(23,24)$. Other less common sources of exposure to dietary lead are ethnic food, dietary supplements, folk medicines and moonshine. Hair/eyelash/eyebrow dyes can be sources of lead poisoning through skin $(24,25)$.

Ingestion of lead does not occur solely through dietary sources. Currently, leadcontaining paint sold in the United States between 1884 and 1978 is the major source of lead ingestion in young American children $(23,24)$. Although the amount of lead allowable in paint was lowered by federal law in 1971 (13), 80\% of U.S. houses were built before 1950which means that 23 million units still contain leaded paint (5). In 2002, it was reported that $65 \%$ of 38 million housing units in the United States had leadbased paint (26). The replacement of

\section{FIGURE 1. Effects of lead poisoning on human health ${ }^{\mathrm{a}}$}

\begin{tabular}{|c|c|c|}
\hline Children & $\mu \mathrm{g} \mathrm{Pb} / \mathrm{dL}$ blood & Adults \\
\hline Learning disabilities & & Hypertension \\
\hline Attention \& IQ deficits & & Neuropathy \\
\hline Anti-social behavior & 10 & $\downarrow$ Memory \\
\hline Headache \& seizure & & Irritability \\
\hline$\downarrow$ Hearing \& growth & & Headache \\
\hline Mental retardation & & $\downarrow$ Hearing acuity \\
\hline Abdominal \& joint pain & & Nephropathy \\
\hline$\downarrow$ Hemoglobin & & Sterility/Impotence \\
\hline Anemia & 50 & $\downarrow$ Hemoglobin \\
\hline Nephropathy & & Longevity \\
\hline Encephalopathy & & $\begin{array}{l}\text { Anemia } \\
\text { Encephalopathy }\end{array}$ \\
\hline Death & & \\
\hline & 150 & \\
\hline
\end{tabular}


white paints containing highly toxic lead compounds with very expensive titanium oxide-based paints and, hopefully in the near future, with non-toxic and inexpensive aluminum phosphate or polyphosphate-based pigments (Biphor ${ }^{\circledR}$, Bunge Co.) (27) might help prevent lead poisoning from paints.

Drinking water can also be contaminated by lead, either at the source due to deposition from environmental sources or in the water distribution system. The U.S. National Primary Drinking Water Regulations for Lead and Copper state that water is unsafe if $10 \%$ of a municipality's test sample is determined to have lead levels greater than 15 ppb (26, 28). Several authors have pointed out that municipal water distribution system infrastructures contain components that may leach lead, such as lead service lines that channel water to the homes, lead pipes inside the homes, copper supply pipes that have been joined using lead solder and lead-containing brass pipes and fixtures that can contain up to $8 \%$ lead $(29,30)$. A recent survey of the Washington, D.C. area by the CDC (31), the D.C. Department of Health and the U.S. Public Health Service estimates that $18 \%$ of over $30 \%$ of the analyzed population residing in this area had BLL above $5 \mu \mathrm{g} / \mathrm{dL}$, leading to cognitive deficits in children $(9,10)$.

In Brazil, Teixeira (32) has found that $11 \%$ of pipes used in the water distribution systems of 100 schools in São Paulo present lead levels above the limit considered safe by the WHO. In $2 \%$ of the water samples, the lead level was found to be five-fold higher than the highest acceptable value $(<10 \mu \mathrm{g} / \mathrm{L}$, according to the WHO), thereby threatening the neuropsychiatric health of children.

Several studies have shown that high BLL in preschool children are strongly correlated with high lead levels in house dust (33-35). This association has been attributed to dust intake from the frequent hand-to-mouth behavior of young children. Flaking lead-based paint, road dust, garden soil and airborne lead-bearing particles are believed to be the sources of lead in household dust (36).

Leaded gas has caused more exposure to the metal than any other source worldwide (37). According to the São Paulo State Health Department (19), about $80 \%$ of the lead found in urban air samples before 1982 was derived from leaded gas. Car battery manufacture is the main source of secondary lead (38), but other sources cannot be discarded. Thus, it is not surprising that international bodies such as the World Bank, WHO and the United Nations Commission on Sustainable Development (CSD) agree that countries must give up leaded gas for the sake of public health. In 1994, the CSD called on governments worldwide to switch from leaded to unleaded petrol. Nevertheless, up to the year 2000, only 42 countries, including China, New Zealand, the United States, some Western and Eastern European countries, and several Latin American countries, had phased out or were phasing out lead from gas. India and a dozen or more countries in Latin America and Western Europe were committed to making the shift by 2005, while the remaining 150 or so countries in the world had not made a decision (39).

\section{BIOCHEMICAL MECHANISMS OF LEAD TOXICITY}

Lead is a heavy metal with no apparent biological function. Despite the extensive evidence concerning the toxic effects of lead on human health, the molecular mechanisms underlying this metal's poisonous effects on the central nervous system (CNS) have yet to be clarified $(40,41)$.

Bioactive lead is a divalent cation that binds strongly to sulfhydryl groups in cysteine residues of proteins and enzymes. Lead toxicity can be largely attributed to conformational changes undergone by enzymes and structural proteins upon binding the lead ion, but this versatile toxic agent has other targets as well. For example, lead interferes with the endogenous opioid system (42) and efficiently breaks the ribosyl phosphate group of tRNA (43). Many toxic properties of lead are putatively due to the metal's capacity to mimic and compete with calcium and zinc ions in finger proteins dependent on these metals (44).

Recent studies have also focused on the heme biosynthetic pathway, where many sites of lead interference are encountered. Thus, lead poisoning can be considered a chemical or acquired porphyria (45). The thiol enzymes $\delta$-aminolevulinic acid dehydratase (ALAD) and ferrochelatase of this pathway are extremely sensitive to lead. Inhibition of these enzymes increases, respectively, ALA and protoporphyrin IX concentrations in urine, blood and other tissues. ALA has long been known to compete with $\gamma$-aminobutyric acid (GABA), a neurotransmitter in the cortex, hypothalamus and other tissues of the CNS and the peripheral nervous system (46).

An increase in ALA in the blood and brain areas could contribute to the triggering of behavior disorders in patients carrying genetic porphyrias, including acute intermittent porphyria (AIP) and hereditary tyrosinemia type 1 , and also in lead poisoned individuals. This hypothesis is based on the fact that ALA has been shown in vitro to exhibit prooxidant properties towards biological molecules (proteins, membranes, DNA) and supramolecular structures (mitochondria, synaptosomes); in vivo, these properties have been observed in brain, liver and red muscles of ALA- or leadtreated rats and in the blood of lead exposed workers (47-52) (Figure 2). Of utmost importance was the finding that ALA-driven oxidative injury to GABA receptors in synaptic membranes, synaptosomes, and GABA-rich brain slices leads to a two-fold increase in the dissociation constant of the receptor-GABA complex (53) and to a significant decrease in the GABA receptor population (54).

Fundamental questions about the molecular basis of the ALA-induced neurological lesions remain unanswered. It is worth noting that acute porphyric attacks of inborn and acquired porphyria patients correlate with elevation of blood and urinary ALA and that lead exposed subjects with high levels of lead $(>60 \mu \mathrm{g} / \mathrm{dL})$ and ALA $(>1 \mu \mathrm{M})$ in the blood present neurological manifestations similar to those in AIP (55-57).

\section{LEAD POISONING OF THE INFANT NERVOUS SYSTEM}

Studies in several countries have estimated that about $4 \%$ of their children have high BLL (20). The prevalence may be even higher in children living in inner-city areas of the United States. According to data collected between 1976 and $1980,17 \%$ of children presented BLL $>15 \mu \mathrm{g} / \mathrm{dL}, 5.2 \%>20 \mu \mathrm{g} / \mathrm{dL}$, and $1.4 \%$ $>25 \mu \mathrm{g} / \mathrm{dL}$ (58). Lead poisoning is not considered a significant environmental risk for children in the rural areas of developing countries. However, in a study with children living in the rural Philippines, $21 \%$ (601 of 2861 children) had 
FIGURE 2. Production of reactive oxygen species by the aerobic oxidation of $\delta$-aminolevulinic acid (ALA), a heme precursor accumulated in lead poisoning, ALA-driven oxidative damage to biomolecules, and biological consequences observed in ALA-treated rats and lead poisoned individuals ${ }^{a}$

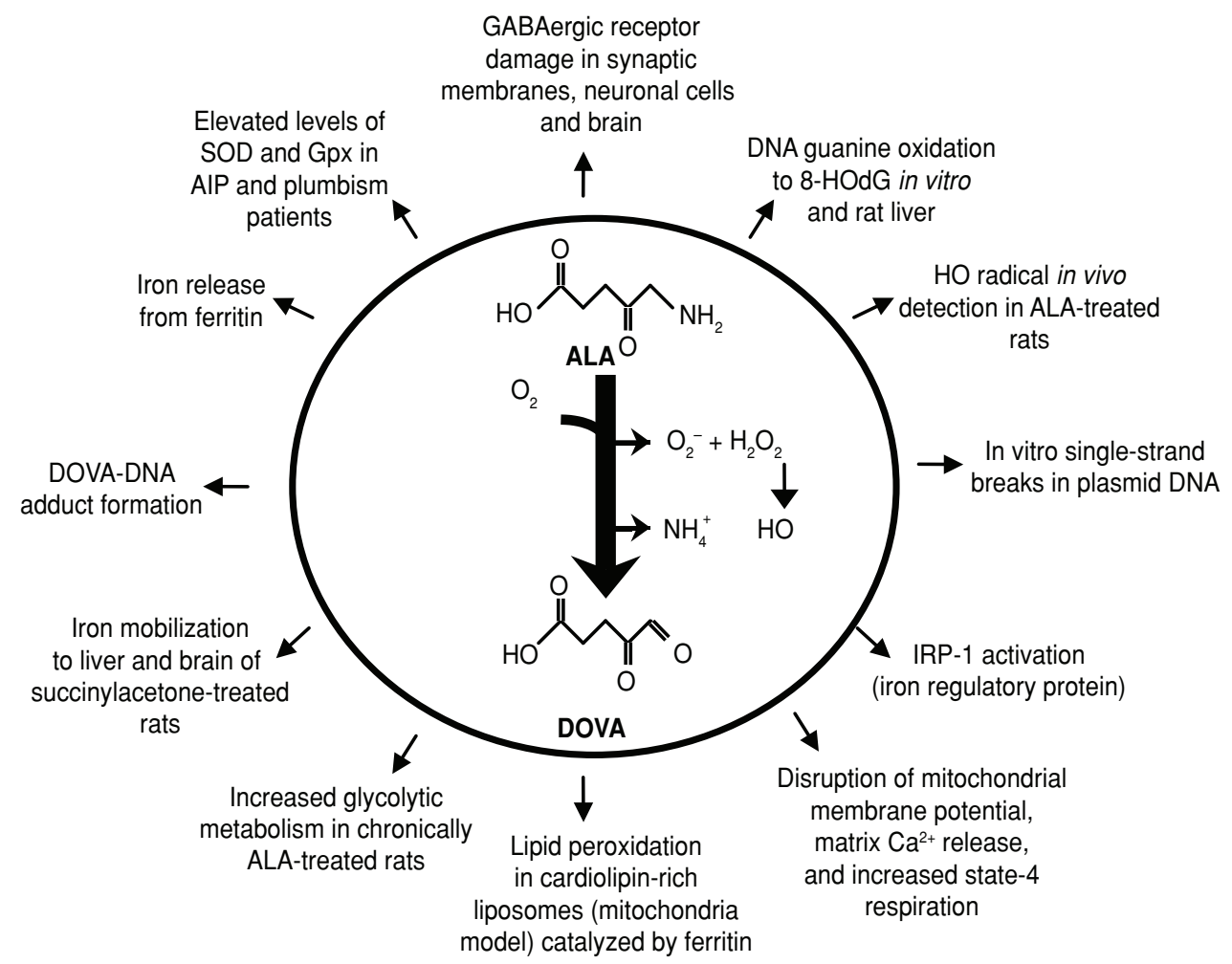

Abbreviations: AIP, acute intermittent porphyria; ALA, $\delta$-aminolevulinic acid; DOVA, 4,5-dioxovaleric acid; GABA, $\gamma$-butyric acid; Gpx, glutathione peroxidase; 8-OHdG, 8-hydroxy-2'deoxyguanosine; IRP, iron regulatory protein; SOD, superoxide dismutase.

${ }^{a}$ Adapted from Bechara et al. (52).

BLL higher than $10 \mu \mathrm{g} / \mathrm{dL}$. BLL were independently associated with age, hemoglobin concentration, water source, roofing material, household expenditures, and history of breastfeeding. The authors evaluated possible environmental exposures in a sub-sample of children with elevated BLL and found multiple potential sources, such as fossil fuel combustion, lead paint (around 38\% of homes) and household items (59).

Children are more sensitive to lead than adults for many reasons. Their exposure to lead is favored by the habit of eating non-nutritive substances (pica habit). A child's intestine absorbs lead much faster than that of an adult, and the developing CNS of infants is more vulnerable to toxic agents than the mature CNS, especially in the case of undernourished children. Neural proliferation, differentiation and plasticity are strongly impaired by lead.

In the United States, overall childhood BLL have declined as a result of federal regulatory measures to reduce population exposure to environmental lead. Screening data from the late 1960s and early 1970s indicate that 20 to $45 \%$ of the children tested had BLL $\geq 40 \mu \mathrm{g} / \mathrm{dL}$. Between 1976 and 1980, the weighted geometric mean of blood lead among 1 to 5year-old children in the United States was $15 \mu \mathrm{g} / \mathrm{dL}$ (60). Data from the Third National Health and Nutrition Examination Survey (NHANES III), phase 1 (1988-1991), showed a decline in the geometric mean of lead level to $3.6 \mu \mathrm{g} / \mathrm{dL}$ (60). NHANES III (1991-1994) showed a further decline in this biomarker to $2.7 \mu \mathrm{g} / \mathrm{dL}$. NHANES III, phase 2 data indicated that approximately $4.4 \%$ of 1 to 5 -year-old children (about 890000 children) had blood levels $\geq 10 \mu \mathrm{g} / \mathrm{dL}$ (61). Bernard et al. (29) analyzed data from NHANES III (1988-1994) and found that the overall prevalence of blood levels $\geq 5 \mu \mathrm{g} / \mathrm{dL}$ was $25.6 \%$, although $76 \%$ of these children had BLL $<10 \mu \mathrm{g} / \mathrm{dL}$.

In Argentina, studies carried out in the cities of Cordoba and Buenos Aires showed that between 10 and $40 \%$ of children younger than 15 years of age presented BLL > $10 \mu \mathrm{g} / \mathrm{dL}$ (62). In Uruguay (63), in the beginning of 2001, BLL > 25 $\mu \mathrm{g} / \mathrm{dL}$ were detected in children from a specific sector of Montevideo where several metal smelting plants and other industrial activities had been in operation for the past 50 years. Because of that, the Uruguayan public health ministry commissioned a second study, which showed that $61 \%$ of 2351 studied children presented BLL > $10 \mu \mathrm{g} / \mathrm{dL}$.

In Brazil, studies on environmental lead exposure are rare, limiting the understanding about the impact of lead on the Brazilian public health (64). SilvanyNeto et al. (65) found mean BLL of $36.7 \pm 20.7 \mu \mathrm{g} / \mathrm{dL}$ in children living close to a primary lead smelting plant in Santo Amaro, state of Bahia. In 1996, using the Zn-protoporphyrin method, the same group (66) found lead levels as high as $65.5 \mu \mathrm{g} / \mathrm{dL}$ in children in the same area These levels have remained abnormally high since 1980 due to the contamination of soil by lead. In 2003, the group found BLL close to $17 \mu \mathrm{g} / \mathrm{dL}$, and $5 \mu \mathrm{g} / \mathrm{dL}$ higher in children with pica habit, independent of age, visible presence of scum surrounding the home, employment status of the father, family history of lead poisoning, and malnutrition (67). 
In Cubatão (state of São Paulo), one of the most industrialized areas of Brazil, Santos Filho et al. (68) found BLL averaging $17.8 \mu \mathrm{g} / \mathrm{dL}$ in the general population. Paoliello (69) found a median BLL of $11.25 \mu \mathrm{g} / \mathrm{dL}$ in children living in the upper Ribeira do Iguape river valley. Freitas (70) carried out an evaluation of lead exposure in a contaminated area of the city of Bauru. In that study, a battery recycling plant had contaminated the neighboring residential area with lead oxides during the previous 8 years. Environmental lead contamination was assessed by the state authority for environmental control CETESB and the plant was closed in 2002. Over half of the 311 children presented BLL between 15 and $19 \mu \mathrm{g} / \mathrm{dL}, 21 \%$ between 20 and $39 \mu \mathrm{g} / \mathrm{dL}$, and less than $1 \%$ (3 children) had BLL of $40 \mu \mathrm{g} / \mathrm{dL}$ or higher. Compared to other lead contaminated areas in Brazil, the BLL found in the Bauru study were rather low (median of $7.3 \mu \mathrm{g} / \mathrm{dL}$ ) (71). In Brazil, there are no public policies establishing an official procedure for sampling and analyzing lead in human tissues, nor to screen lead in schoolchildren, even in the presence of psychomotor and learning disabilities (19).

\section{Lead effects on IQ and social behavior}

Cognitive function, measured by psychometric IQ tests, has been the major focus of most studies on lead exposure in childhood. However, there are reasons to believe that cognitive dysfunction may not be the most important effect of lead (5).

Denno (72) traced the behavioral patterns of 987 African-American youths from birth to age 22. She found that among the dozens of sociologic and biologic correlates of delinquency, lead poisoning was among the strongest for male subjects. Lead-induced aggressiveness is not an entirely new notion. Parents have frequently reported a dramatic change in the behavior of children after recovery from an episode of acute lead poisoning, with the child becoming restless, inattentive and aggressive (5). In 1943, Byers and Lord reported attention deficits and aggression in a sample of lead-poisoned children (15).

Needleman et al. (73) studied 301 primary school students and found that children with elevated bone lead levels scored higher on the attention-deficit, aggression, and delinquency clusters of the Child Behavior Checklist after adjustment of covariates. Dietrich et al. (74) found that prenatal lead exposure was associated with parental reports of delinquency and aggression, and postnatal lead exposure was associated with selfreports of delinquent acts. A case-control study including 194 arrested and convicted delinquent youths (aged 12 to 18 years) and 146 non-delinquent controls revealed an increased risk of delinquency associated with bone lead concentrations measured by $\mathrm{X}$-ray fluorescence (75). The covariate-adjusted odds ratio was 4 (95\% CI: 1.4-11.1). In Brazil, a cross-sectional study was conducted to verify the association between dental enamel lead levels and anti-social behavior. The study included 173 adolescents aged 14 to 18 years and their parents $(n=93)$, residents of impoverished neighborhoods in the city of Bauru (state of São Paulo), a region with high crime rates. The covariate-adjusted odds ratios indicated that high dental enamel lead levels were associated with increased risk of externalizing problems and of exceeding the clinical score for somatic complaints, social problems, and rulebreaking behavior. The authors concluded that exposure to high lead levels can indeed trigger antisocial behavior, which claims for public policies to prevent lead poisoning in the country (76).

Recently, Chiodo et al. (77) have shown a relationship between BLL and neurobehavioral outcome in 7-year-old African American children. Among the studied variables, social problems, delinquent behavior and total behavior problem scores were associated with BLL $(\beta=0.10, \beta=0.09$ and $\beta=0.09 ; P<0.05)$.

A number of recent ecological investigations have correlated leaded gasoline sales and lead in air particulates with crime rates, strongly suggesting an association between lead exposure and crime. Stretesky and Lynch (78), when comparing homicide rates in 3111 counties in the United States with adjustment for 15 covariates, reported a four-fold increase in homicide rates in counties with the highest air lead levels compared to controls. Nevin (79) correlated sales of leaded gasoline with violent crime rates and, after adjustment for unemployment and percent of population in the highcrime age group, found a statistically significant association between lead and crime. It has been speculated that one of the reasons for the recent decline in crime rates in the United States might be attributed to the adoption of public policies to ban lead in paints, gas, and canned food, therefore reducing exposure to lead. In 2007, Nevin (80) carried out single and combined national regressions, identifying "best-fit" lags for each crime analyzed, with the highest significance ( $t$-value) for blood lead and percent of crime rate variation explained $\left(\mathrm{R}^{2}\right)$. The results presented a strong association between preschool blood lead and subsequent crime rate trends over several decades in nine countries. Furthermore, regression analyses of the average murder rates for the period between 1985 and 1994 in American cities suggests that murder could be especially associated with more severe cases of childhood lead poisoning.

Many studies provide evidence of an inverse relationship between lead exposure and cognitive ability (81). There is, however, disagreement about the IQ to blood lead slope (IQ points lost per increase of $1 \mu \mathrm{g} / \mathrm{dL}$ in blood lead) and the influence of confounding variables (82, 83). There is strong evidence that young children face the greatest risk of IQ losses due to lead exposure, especially during the first 3 years of life, when basic cognitive abilities develop (82). This information is very important because many painted toys may contain lead, posing risk especially because children are likely to introduce them into their mouths. Cognitive losses due to lead exposure during the first 3 years of life appear to be most evident in IQ tests carried out some years later, around age 10 or older, when IQ scores are more stable and predictive of future outcomes (81, 82). There is no consensus, however, on whether lead exposure is more strongly associated with verbal IQ, mathematical skills or performance IQ. However, despite the similarity with a pattern of outcomes typical of brain injury, detailed comparisons of children's deficits indicate that lead, like most other causes of brain injury, does not produce exactly the same set of impairments in all patients (84).

Although data on yearly changes in IQ are unavailable, temporal data are available for specific types of social behavior associated with lower IQ scores. Herrnstein and Murray (85), in their controversial book The Bell Curve, cite data showing that individuals with lower IQ levels 
account for a disproportionate share of violent crime and unwed births.

In 1960, in the United States, the accepted threshold for BLL in children was $60 \mu \mathrm{g} / \mathrm{dL}$. Follow-up studies carried out in American cities showed that 10 to $20 \%$ of the children in these cities presented BLL of up to $40 \mu \mathrm{g} / \mathrm{dL}$. This finding supported the notion that some learning difficulties and behavior disorders (subclinical manifestations) could be attributed to lead. Five studies on lead levels and behavior in children without overt signs or symptoms of lead poisoning were carried out in the 1970s. Three of them reported an association between lead and IQ $(16,17)$, and two did not confirm this connection $(86,87)$. Those studies had limitations of design: the number of patients in each study was small, and blood lead was used as a biomarker. Blood lead is reliable as a biomarker of short-term exposure only, since it has a half-life of 36 days in the blood (88).

Three meta-analyses have confirmed that exposure to low levels of lead may be associated with IQ deficiency $(82,83$, 89). In response to these data, in 1991, the CDC reviewed the acceptable levels for BLL, reducing the $60 \mu \mathrm{g} / \mathrm{dL}$ blood threshold established in 1970 to the present value of $10 \mu \mathrm{g} / \mathrm{dL}$. More recent data point toward cognitive, attention and behavior deficits in children with BLL between 3 and $5 \mu \mathrm{g} / \mathrm{dL}$ (9). In 2007, Chiodo et al. (77) presented data showing that a threshold below which BLL is not associated with harmful outcomes does not exist. The authors suggest a reduction of the "acceptable" level, considering the recent scientific evidence. Dudek and Merecz (90) found that the fastest deterioration of IQ was observed with BLL between 5 and 10 and 11 to $15 \mu \mathrm{g} / \mathrm{dL}$, consistent with the finding by Schwartz (82) of an increased slope at lower BLL (79).

In recent decades, violent crime and unwed pregnancies have been associated with teenagers and young adults living in poor urban areas. The average BLL in children from deprived urban areas has probably begun to rise as early as the 1940s, due to the addition of tetraethyl lead to gasoline combined with use of lead-based pigments in house paints. Therefore, temporal data on leaded gasoline consumption might serve as a rough indicator for changes in blood lead in poor urban children from 1940 to 1987 . If childhood lead exposure affects IQ, and
IQ affects population rates for crime and unwed pregnancy, then changes in crime and unwed pregnancy rates from 1960 to the late 1990s could reflect changes in IQ associated with temporal trends in leaded gasoline consumption from 1940 through the early 1980s (79).

\section{PRIMARY PREVENTION: BENEFITS FOR PUBLIC HEALTH}

A cost-benefit analysis carried out by the United States Public Health Service estimated the cost of abatement of old houses painted with lead-containing paints over a 30-year period at US\$33.7 billion, in 1991. The estimated benefit from avoided health care costs and increased income due to raised IQ would be US $\$ 61.7$ billion. This cost analysis may be conservative, as it does not contemplate the prevention of delinquency and cardiovascular disease, both demonstrated effects of lead exposure, among other health effects (4).

According to Needleman (5), current analyses also demonstrate that prevention of primary lead exposure yields large economic benefits. Grosse et al. (91) calculated that the IQ of preschool children was increased by 2.2 to 4.7 points above what it might have been if leaded gasoline and blood lead had not been reduced. From this, they calculated the IQrelated increase in income and estimated that the economic benefit for each year's birth cohort was between US\$110 and US\$319 billion. Landrigan et al. (92), assuming no threshold for the lead-IQ association, estimated the loss of future earnings for the 1-year cohort of children aged 5 in 1997 at US\$43.4 billion.

The monetary cost associated with the ubiquitous exposure of fetuses and children to lead in industrialized societies has also been calculated by Schwartz (93). That author estimated medical costs associated with the treatment of children with undue lead exposure, the increase in remedial education, and the costs associated with reduced birth-weight and reduced gestational age, among other factors. The largest single cost was earnings lost as a result of decreased intellectual capability (Table 1). According to another analysis using the comprehensive National Longitudinal Survey of Youth database to attribute monetary value to the effect of decreased cognitive ability on earning capacity, the estimated gain in earnings would be US\$7.5 billion
TABLE 1. Annual benefits of a $1 \mu \mathrm{g} / \mathrm{dL}$ reduction in the mean blood lead concentration of the infant population in the United States ${ }^{a}$

\begin{tabular}{lr}
\hline \multicolumn{1}{c}{ Annual benefits } & US\$ million \\
\hline Medical costs & 189 \\
Compensatory education & 481 \\
Infant mortality & 1,140 \\
Neonatal care & 67 \\
Earnings & 5,060 \\
$\quad$ Total & 6,937 \\
\hline
\end{tabular}

according to Schwartz (93).

per year for a decrease of $1 \mu \mathrm{g} / \mathrm{dL}$ in BLL in the U.S. population (94). It is obvious that the effect of lead on IQ represents an enormous cost to society in terms of lost potential and increased need for medical care and special education.

According to Needleman (5), the evidence that lead toxicity extends down to the lowest measurable levels, that pharmacological therapies are ineffective at preventing sequelae in those with low levels, and that reduction of exposure yields huge economic as well as health benefits provides a strong argument in favor of the systematic abatement of lead from the single remaining major source in the United States: older homes. On the other hand, an association has been firmly established between air lead concentrations and levels of lead in the body (95-99). To determine if data on potential lead exposure drawn from the Environmental Protection Agency's Cumulative Exposure Project (CEP) were correlated with BLL at the county level, Stretesky and Lynch (78) collected data from the Ohio Department of Health on children younger than 6 years who had BLL above $10 \mu \mathrm{g} / \mathrm{dL}$ in 1998. The CDC identified the data from Ohio as more valid than data from most states because a large proportion of children across all Ohio counties are tested for lead poisoning. The authors found that across Ohio's counties, CEP-estimated air lead concentrations were positively and significantly correlated with the percentage of children (among children who were screened) who had elevated BLL (Pearson correlation coefficient: $0.44 ; P<0.001 ; n=88)$. This relationship persisted (Pearson correlation coefficient, $0.48 ; P<0.001 ; n=88$ ) after adjustment for the percentage of houses built before the 1950s (1990 census estimate), reinforcing previous findings suggesting that lead exposure may result from a variety of contamination sources, including lead-contaminated air. 
An important and interesting example of primary prevention is that of the city of Hartford, state of Connecticut, in the United States. The Hartford Health Department implemented a public health campaign to increase the lead poisoning awareness. The actions involved several novel elements and partnerships, including the use of municipal sanitation trucks to disseminate lead-poisoning prevention messages throughout the city. The most important results were as follows: recall of campaign components ranged from 21.5 to $62.6 \%$, with newspaper advertisements and signs on buses and billboards recalled most often and a video broadcast on public-access television recalled least often; more than $45 \%$ of respondents reported that they took steps to prevent lead poisoning because of at least one of the campaign items, with newspaper advertisements being the most effective component in terms of prompting lead-poisoning prevention behavior. However, the awareness of respondents was particularly low concerning how medical personnel and procedures could or could not detect and prevent lead poisoning in children. This campaign inspired caregivers to take the necessary steps to prevent lead poisoning and may help public health professionals in other communities to develop new ideas for similar initiatives (100).

In Brazil, according to the São Paulo State Health Department, some measures have been adopted for protecting the population, despite the lack of an official program for environmental lead exposure prevention. Since 1978, tetraethyl lead has no longer been added to gasoline as an anti-detonator. In addition, there are regulations for acceptable lead levels in food and water (101, 102). Regarding acceptable levels in humans, until recently only occupational exposure had been regulated. In 2008, however, a law was enacted to establish the maximum amount of lead in the manufacture of materials for children in educational

1. Major RH. Some landmarks in the history of lead poisoning. Ann Med Hist. 1931;3: 218-27.

2. Satcher DS. The surgeon general on the continuing tragedy of childhood lead poisoning. Public Health Rep. 2000;115(6):579-80.

3. Lin-Fu JS. Health effects of lead, an evolving concept. In: Mahaffey KR, editor. Dietary settings, as well as in varnishes and furniture (103). It should be noted that before this law some manufacturers from non-regulated sectors followed internationally accepted lead parameters. According to the Brazilian Association of Paint Manufacturers, there is a trend that began in the 1990s to replace lead pigments in paints. At present, Brazilian domestic paints are free of lead. However, lead is still used as an anti-corrosive, such as red lead in iron gates, refrigerators, cars, stoves, bicycles, and many other goods. In this case, a covering paint must be applied (19). As mentioned, the non-toxic and inexpensive Biphor ${ }^{\circledR}$ white pigment, based on aluminum phosphates and polyphosphates, will greatly decrease paint-related lead poisoning (27). Still in Brazil, studies conducted at the Adolfo Lutz Institute (104) have found lead in pencils, pens, colored paints, erasers and other school supplies. This study recommended the drawing of regulatory guidelines for the manufacture of such products, which are now regulated by the 2008 law mentioned earlier (103).

Canned food manufacturers in Brazil have also replaced lead-based solders. Regarding the contamination of fresh food by lead, Sakuma (105) found secure lead levels for human consumption in Brazil. Glazed ceramic containers can be a source of lead poisoning when lead leaches into stored beverages, especially in the case of acidic fruit juices such as those made from grapes and citrus fruit (106). Lead from glazed ceramics is promptly dissolved by the tartaric and citric acids present in these juices, due to the chelation of the metal by these acids.

Since 1986, an Environmental Impact Report (EIA/RIMA) has been officially required for the approval of potentially polluting industrial plants, as an obligatory document to license these companies (107). The strategies proposed in this report to minimize the pollution by the plant must be analyzed and ap- proved (102). Nevertheless, companies started before 1986 are not mandated to follow this protocol, unless they have caused environmental damage (108). According to information from the São Paulo State Health Department Sanitary Vigilance Center (19), several small companies and domestic sources of lead contamination do not issue warnings to prevent lead exposure.

\section{FINAL REMARKS}

Considering that a healthy social tissue can be seriously harmed by lead, it is extremely important to establish public policies against lead contamination and guarantee an adult population that is socially well balanced and productive. In a recent paper, provocatively named "Childhood lead poisoning prevention-too little, too late," Lanphear (109) calls attention to the importance of preventing lead poisoning for the good of individuals and of society. In this context, it is tempting to state that there is a high probability that many young delinquents are actually victims of lead poisoning and not necessarily genetic or social criminals. We close with a plea for public health policies to prevent lead poisoning in underdeveloped and developing countries, such as those that have long been adopted in the United States, Europe, and Japan.

Acknowledgements. This work was supported by grants from Fundação de Amparo à Pesquisa do Estado de São Paulo (FAPESP), Conselho Nacional de Desenvolvimento Científico e Tecnológico (CNPq), and Projeto Milênio Redoxoma. $\mathrm{KPKO}$ is the recipient of a fellowship from Coordenação de Aperfeiçoamento de Pessoal de Nível Superior (CAPES). The authors are indebted to Prof. Abner Lall (Howard University, USA) and to Dr. Brian Bandy (University of Saskatchewan, Canada) for kindly revising this manuscript.

\section{REFERENCES}

and environmental lead: human health effects. Amsterdam: Elsevier; 1985. Pp. 58-9. (Topics in Environmental Health vol. 7).

4. Centers for Disease Control and Prevention. Preventing lead poisoning in young children: a statement. Atlanta: U.S. Department of Health and Human Services, Public Health Services; 1991.
5. Needleman H. Lead poisoning. Annu Rev Med. 2004;55:209-22.

6. Lidsky TI, Schneider JS. Lead neurotoxicity in children: basic mechanisms and clinical correlates. Brain. 2003;126(Pt 1):1-19.

7. Lin-Fu JS. Undue absorption of lead among children: a new look at an old problem. N Engl J Med. 1972;286(13):702-10. 
8. Bellinger DC. Lead. Pediatrics. 2004;113(4 Suppl):1016-22.

9. Lanphear BP, Dietrich K, Auinger P, Cox C. Cognitive deficits associated with blood lead concentrations $<10 \mu \mathrm{g} / \mathrm{dL}$ in U.S. children and adolescents. Public Health Rep. 2000; 115(6):521-9.

10. Canfield RC, Henderson CR, Cory-Slechta DA, Cox C, Jusko TA, Lanphear BP. Intellectual impairment in children with blood lead concentrations below $10 \mu \mathrm{g}$ per deciliter. $\mathrm{N}$ Engl J Med. 2003;348(16):1517-26.

11. Chiodo LM, Jacobson SW, Jacobson JL. Neurodevelopmental effects of postnatal lead exposure at very low levels. Neurotoxicology. 2004;26(3):359-71.

12. Blackfan KD. Lead poisoning in children with especial reference to lead as a cause of convulsions. Am J Med Sci. 1917;53:877-87.

13. Agency for Toxic Substances and Disease Registry (ATSDR). Case studies in environmental medicine. Lead toxicity: Where is lead found? Available from: http://www. atsdr.cdc.gov/csem/lead/pbwhere_found2. html. Accessed 19 July 2009.

14. Levinson A, Harris LH. Lead encephalopathy in children. J Pediatr. 1936;8:315-29.

15. Byers RK, Lord EE. Late effects of lead poisoning on mental development. Am J Dis Child. 1943;66(5):471-83.

16. De La Burne B, NcLin S, Choate S. Does asymptomatic lead exposure in children have latent sequelae? J Pediatr. 1972;81(6): 1088-91.

17. Perino J, Ernhart CB. The relation of subclinical lead level to cognitive and sensorimotor impairment in black preschoolers. J Learn Disabil. 1974;7(10):26-30.

18. Landrigan PJ, Baloh RW, Barthel WF. Neuropsychological dysfunction in children with low level lead absorption. Lancet. 1975; 1(7909):708-12.

19. Freitas CU. Estratégias de abordagem para a exposição ambiental ao chumbo no Estado de São Paulo. Available from: http:// www.cve.saude.sp.gov.br/htm/doma/ chumbo. htm. Accessed 1 December 2006

20. World Health Organization. Human exposure to lead. Report on the Human Exposure Assessment Location (HEAL) Programme Meeting held in Bangkok, Thailand, 16-19 Nov 1992. Available from: whqlibdoc.who. int/hq/1995/WHO_EHG_95.15.pdf. Accessed 24 July 2009.

21. Mangas S, Fitzgerald DJ. Exposures to lead require ongoing vigilance. Bull World Health Organ. 2003;81(11):847.

22. Goyer RA. Results of lead research: prenatal exposure and neurological consequences. Environ Health Perspect. 1996;104(10):1050-4.

23. Mielke HW. Lead in inner cities. Am Sci. 1999;87(1):62-73.

24. United States. Food and Drug Administration. FDA consumer. Dangers of lead still linger. Available from: http://www.cfsan. fda.gov/ dms/fdalead.html. Accessed 23 October 2006.

25. Lynch RA, Boatright DT, Moss SK. Leadcontaminated imported tamarind candy and children's blood lead levels. Public Health Rep. 2000;115(6):537-43.

26. Jacobs DE, Clickner RP, Zhou JY, Viet SM, Marker DA, Rogers JW, et al. The prevalence of lead-based paint hazards in U.S. housing.
Environ Health Perspect. 2002;110(10):A599A606.

27. Galembeck F, De Brito J. Aluminum phosphate or polyphosphate particles for use as pigments in paints and method of making same. U.S. Pat Appl Publ 2006; Application U.S. 2005-215312 20050830.

28. United States. Environmental Protection Agency. National primary drinking water regulations: consumer confidence; proposed rule, in CFR 1998; 40:141-142. Available from: http://www.regulations.gov/fdms public/component/main. Accessed 24 January 2007.

29. Bernard SM, Samet JM, Grambsch A, Ebi KL, Romieu I. The potential impacts of climate variability and change on air pollution related health effects in the United States. Environ Health Perspect. 2001;109(2 Suppl): 199-209.

30. Maas RP, Patch SC, Parker AF. An assessment of lead exposure potential from residential cutoff valves. J Environ Health. 2002;65 (1):9-14.

31. Centers for Disease Control and Prevention. Blood lead levels in residents of homes with elevated lead in tap water-District of Columbia. MMWR Morb Mortal Wkly Rep. 2004;53(12):268-70.

32. Teixeira P. Encanamentos inadequados podem contaminar a água com chumbo. Agência USP de notícias 2002. Available from: http://www.usp.br/agen/. Accessed 6 December 2006.

33. Charney E, Kessler B, Fartel M, Jackson D. Childhood lead poisoning: a controlled trial of the effect of dust-control measures on blood lead levels. N Engl J Med. 1983; 309(18):1089-93.

34. Tornton I, Davies DJA, Watt JM, Quinn MJ. Lead exposure in young children from dust and soil in the United Kingdom. Environ Health Perspect. 1990;89:55-60.

35. Rhoads GG, Ettinger AS, Weisel CP, Buckley TJ, Goldman KD, Lioy PJ. The effect of dust lead control on blood lead in toddlers: a randomized trial. Pediatrics. 1999;103(3): 551-5.

36. Yiin LM, Rhoads GG, Lioy PJ. Seasonal influences on childhood lead exposure. Environ Health Perspect. 2000;108(2):177-82.

37. Landrigan PJ. The worldwide problem of lead in petrol. Bull World Health Organ. 2002;80(10):768.

38. Paoliello MMB, Capitani EM. Chumbo. In: Azevedo FA, Chasin AM. Metais: gerenciamento da toxicidade. São Paulo: Atheneu Inter Tox; 2003. Pp. 359-60.

39. Gavaghan H. Lead, unsafe at any level. Bull World Health Organ. 2003;80(1):82.

40. Toscano CD, Guilarte TR. Lead neurotoxicity: from exposure to molecular effects. Brain Res Rev. 2005;49(3):529-54.

41. Moreira FR, Moreira JC. Os efeitos do chumbo sobre o organismo humano e seu significado para a saúde. Rev Panam Salud Publica. 2004;15(2):119-29.

42. Bailey C, Kitchen I. Ontogenesis of proenkephalin products in rat striatum and the inhibitory effects of low-level lead exposure. Dev Brain Res. 1985;354(1):75-9.

43. Brown RS, Hingerty BE, Dewan JC. Pb (II)catalyzed cleavage of the sugar-phosphate backbone of yeast tRNA (Phe)-implications for lead toxicity and self-splicing RNA. Nature. 1983;303(5917):543-6.

44. Markovac J, Goldstein GW. Picomolar concentrations of lead stimulate brain protein kinase C. Nature. 1988;334(6177):71-3.

45. Chisolm Jr JJ. Lead poisoning. Sci Am. 1971; 224(2):15-23.

46. Monteiro HP, Bechara EJH, Abdalla DSP. Free radicals involvement in neurological porphyrias and lead poisoning. Mol Cell Biochem. 1991;103(1):73-83.

47. Bechara EJH. Oxidative stress in acute intermittent porphyria and lead poisoning may be trigged by 5 -aminolevulinic acid. Braz J Med Biol Res. 1996;29(7):841-51.

48. Costa CAC, Trivelato GC, Pinto AMP, Bechara EJH. Correlation between plasma 5aminolevulinic acid concentrations and indicators of oxidative stress in lead-exposed workers. Clin Chem. 1997:43(7):1196-202.

49. Gurer H, Ercal N. Can antioxidants be beneficial in the treatment of lead poisoning? Free Radic Biol Med. 2000;29(10):927-45.

50. Aykin-Burns N, Laegeler A, Kellogg G, Ercal $\mathrm{N}$. Oxidative effects of lead in young and adult Fisher 344 rats. Arch Environ Contam Toxicol. 2003:44(3):417-20.

51. Rocha MEM, Dutra F, Bandy B, Baldini RL, Gomes SL, Faljoni-Alário A, et al. Oxidative damage to ferritin by 5 -aminolevulinic acid. Arch Biochem Biophys. 2003;409(2):349-56.

52. Bechara EJH, Dutra F, Cardoso VES, Sartori A, Olympio KPK, Penatti CAA, et al. The dual face of alpha endogenous aminoketones: pro-oxidizing metabolic weapons. Comp Biochem Physiol, Part C: Toxicol Pharmacol. 2006;146(1-2):88-110.

53. Demasi M, Costa CA, Pascual C, Lesuy S, Bechara EJH. Oxidative tissue response promoted by 5 -aminolevulinic acid promptly induces the increase of plasma antioxidant capacity. Free Rad Res. 1996;26(3):235-46.

54. Adhikari A, Penatti CA, Resende RR, Ulrich $\mathrm{H}$, Britto LR, Bechara EJ. 5-Aminolevulinate and 4,5-dioxovalerate ions decrease GABA(A) receptor density in neuronal cells, synaptosomes and rat brain. Brain Res. 2006; 1093(1) 95-104.

55. Anderson KE. Doenças das porfirinas ou metais. In: Wyngaarden JB, Lloyd $\mathrm{H}$, Bennett JC, editors. Cecil tratado de medicina interna. Rio de Janeiro: Guanabara Koogan; 1993. Pp. 1146-51.

56. Bechara EJH, Medeiros MHG, Monteiro HP, Hermes Lima M, Pereira B, Demasi M, et al. A free radical hypothesis of lead poisoning and inborn porphyries associated with 5aminolevulinic acid overload. Quim Nova. 1993;16:385-92.

57. Bechara EJH, Medeiros MHG, Catalani LH, Soares CHL, Monteiro HP, Abdalla DSP, et al. Enolizable carbonyl and imino metabolites may act as endogenous sources of reactive oxygen species. Cienc Cult. 1995;47 (5/6):346-57.

58. Centers for Disease Control and Prevention. Current trends childhood lead poisoning: reports to the Congress by the Agency for toxic substances and disease registry. MMWR Morb Mortal Wkly Rep. 1988;37(32): 481-5.

59. Riddell TJ, Solon O, Quimbo SA, Tan CM Butrick E, Peabody JW. Elevated bloodlead levels among children living in the rural 
Philippines. Bull World Health Organ. 2007; 85(9):674-80.

60. Pirkle JL, Brody DJ, Gunter EW, Kramer RA, Paschal DC, Flegal KM, et al. The decline in blood lead levels in the United States: the National Health and Nutritional Examination Surveys (NHANES). JAMA. 1994;272(4): 284-91.

61. Centers for Disease Control and Prevention. Update: blood lead levels-United States, 1991-1994. MMWR Morb Mortal Wkly Rep. 1997;46(7):141-6.

62. Garcia SI, Mercer R. Salud infantil y plomo en Argentina. Salud Publ Mex. 2003;45(2 Suppl): s252-5.

63. Manay N, Alonzo C, Dol I. Contaminación por plomo en el bairro La Teja; Montevideo, Uruguay. Salud Publ Mex. 2003;45(2 Suppl): s268-s75.

64. Franco-Netto G, Alonzo MD, Cancio J, Jost $\mathrm{M}$, Souza-Oliveira S. Human health risk reduction due to lead exposure in Brazil. Salud Publ Mex. 2003;45(2 Suppl):s255-7.

65. Silvany-Neto AM, Carvalho FM, Chaves MEC, Brandão AM, Tavares TM. Repeated surveillance of lead poisoning among children. Sci Total Environ. 1989;78:179-86.

66. Silvany-Neto AM. Evolução da intoxicação por chumbo em crianças de Santo Amaro, Bahia 1980, 1985 e 1992. Bol Oficina Sanit Panam. 1996;120(1):11-2.

67. Carvalho FM, Silvany Neto AM, Tavares TM, Costa ACA, Chaves CER, Nascimento LD, et al. Chumbo no sangue de crianças e passivo ambiental de uma fundição de chumbo no Brasil. Rev Panam Salud Publica. 2003;13(1):19-23.

68. Santos Filho E, Souza e Silva R, Barretto HHC, Inomata ONK, Lemes VRR, Sakuma $\mathrm{AM}$, et al. Concentrações sanguíneas de metais pesados e praguicidas organoclorados em crianças de 1 a 10 anos. Rev Saude Publica. 1993;27(1):59-67.

69. Paoliello MMB. Human lead exposure in mining areas, Vale do Ribeira, Brazil $[\mathrm{PhD}$ dissertation]. Campinas: Universidade Estadual de Campinas; 2002

70. Freitas CU. Vigilância de população exposta a chumbo no município de Bauru-São Paulo: investigação de fatores de risco de exposição e avaliação da dinâmica institucional [PhD dissertation]. São Paulo: Faculdade de Saúde Pública, Universidade de São Paulo; 2004.

71. Freitas CU, Capitani EM, Gouveia N, Simonetti MH, Paula e Silva MR, Kira CS, et al. Lead exposure in an urban community: investigation of risk factors and assessment of the impact of lead abatement measures. Environ Res. 2007;103(3):338-44.

72. Denno DW. Biology and violence. New York: Cambridge University Press; 1990.

73. Needleman HL, Riess JA, Tobin MJ, Biesecker GE, Greenhouse JB. Bone lead levels and delinquent behavior. JAMA. 1996;275(5): 363-9.

74. Dietrich KN, Ris MD, Succop PA, Berger OG, Bornschein RL. Early exposure to lead and juvenile delinquency. Neurotoxicol Teratol. 2001;23(6):511-8.
75. Needleman HL, McFarland C, Ness RB, Fienberg SE, Tobin MJ. Bone lead levels in adjudicated delinquents. A case control study. Neurotoxicol Teratol. 2002;24(6):711-7.

76. Olympio KPK, Oliveira PV, Naozuka J, Cardoso MRA, Günther WMR, Bechara EJH. Surface dental enamel lead levels and antisocial behavior in Brazilian adolescents [abstract]. Toxicologist (Toxicol Sci Suppl). 2009;108:76.

77. Chiodo LM, Covington C, Sokol RJ, Hannigan JH, Jannise J, Ager J, et al. Blood lead levels and specific attention effects in young children. Neurotoxicol Teratol. 2007;29(5): 538-46.

78. Stretesky PB, Lynch MJ. The relationship between lead exposure and homicide. Arch Pediatr Adolesc Med. 2001;155(5):579-82.

79. Nevin R. How lead exposure relates to temporal changes in IQ, violent crime and unwed pregnancy. Environ Res. 2000;83(1): $1-22$.

80. Nevin R. Understanding international crime trends: the legacy of preschool lead exposure. Environ Res. 2007;104(3):315-36.

81. National Research Council. Committee on Measuring Lead in Critical Populations. Measuring lead exposure in infants, children and other sensitive populations. Washington DC: National Academy Press; 1993.

82. Schwartz J. Low-level lead exposure and children's IQ: a meta-analysis and search for a threshold. Environ Res. 1994;65(1):42-55.

83. Pocock SJ, Smith M, Baghurst P. Environmental lead and children's intelligence: a systematic review of the epidemiological evidence. BMJ. 1994;309(6963):1189-97.

84. Lidsky TI, Schneider JS. Adverse effects of childhood lead poisoning: the clinical neuropsychological perspective. Environ Res. 2006;100(2):284-93.

85. Herrnstein R, Murray C. The Bell curve: intelligence and class structure in American life. New York: Free Press; 1994.

86. Kotok D. Development of children with elevated blood levels: a controlled study. J Pediatr. 1972;80(1):57-61.

87. Lansdown RG, Shepherd J, Clayton BE. Blood lead levels, behavior and intelligence. A population study. Lancet. 1974; 1(7857):538-41.

88. World Health Organization. Environmental health criteria 165-Inorganic lead. Geneva: WHO, 1995. [Published under the joint sponsorship of the United Nations environment programme, the International Labour Organization, and the World Health Organization].

89. Needleman HL, Gatsonis C. Low level lead exposure and the IQ of children. JAMA, J Am Med Assoc. 1990;263(5):673-8.

90. Dudek B, Merecz D. Impairment of psychological functions in children environmentally exposed to lead. Int J Occup Med Environ Health. 1997;10(1):37-46.

91. Grosse SD, Matte TD, Schwartz J, Jackson RJ. Economic gains resulting from the reduction in children's exposure to lead in the United States. Environ Health Perspect. 2002;110(6): 563-70.
92. Landrigan PJ, Schechter CB, Lipton JM, Fahs MC, Schwartz J. Environmental pollutants and disease in American children: estimates of morbidity, mortality, and costs for lead poisoning, asthma, cancer and developmental disabilities. Environ Health Perspect. 2002;110(7): 721-8.

93. Schwartz J. Societal benefits of reducing lead exposure. Environ Res. 1994;66(1):105-24.

94. Salveker DS. Updated estimates of earnings benefits from reduced exposure of children to environmental lead. Environ Res. 1995; 70(1): $1-6$.

95. Brunkenreff $B$. The relationship between air lead and blood lead in children. Sci Total Environ. 1984;38:79-123.

96. Nriagu JO, Kim MJ. Emissions of lead and zinc from candles with metal-core wicks. Sci Total Environ. 2000;250(1-3):37-41.

97. Hayes EB, McElvaine MD, Hyman GO, Fernandez AM, Lyne S, Matte TD. Long-term trends in blood lead levels among children in Chicago: relationship to air lead levels. Pediatrics. 1994;93(2):195-200.

98. Lai JS, Wu TN, Liou SH, Shen CY, Gun CF, $\mathrm{Ko} \mathrm{KN}$, et al. A study of the relationship between ambient lead and blood lead among lead battery workers. Int Arch Occup Environ Health. 1997:69(4):295-300.

99. Thomas VM, Socolow RH, Fanelli JJ, Spiro TG. Effects of reducing lead in gasoline: an analysis of the international experience. Environ Sci Technol. 1999;33(22):3942-84.

100. McLaughlin T, Humphries Jr O, Nguyen T, Maljanian R, McCormack K. "Getting the lead out" in Hartford, Connecticut: a multifaceted lead-poisoning awareness campaign. Environ Health Perspect. 2004;112(1):1-5.

101. Portaria $\mathrm{n}^{\circ} 16$, de 13 de março de 1990. Diário Oficial da União 1990. March 15: section 1: 5436.

102. Resolução CONAMA n ${ }^{\circ}$ 357. Diário Oficial da União 2005. March 18.

103. Brasil. Lei $\mathrm{n}^{\circ} 11762$ de $1^{\circ}$ de agosto de 2008 . Available from: http://www.planalto.gov. br/ccivil_03/_Ato2007-2010/2008/Lei/ L11762.htm. Accessed 7 October 2008.

104. Garrido NS, Pregnolatto NP, Murata LTF, Silva MR, Nunes MCD, Engler VM, et al. Determinação de chumbo e cádmio em artigos escolares. Rev Inst Adolfo Lutz. 1990;50(1/2): 291-6.

105. Sakuma AM, Scorsafava MA, Zenebon O, Tiglea P, Fukumoto CJ. Hortaliças comercializadas em São Paulo: aspectos da contaminação de chumbo, cádmio e zinco. Rev Inst Adolfo Lutz. 1989;49(1):81-4.

106. Browder AA. Lead poisoning from glazes. Ann Intern Med. 1972;76(4):665.

107. Resolução CONAMA n ${ }^{\circ}$ 237. Diário Oficial da União 1997. December 22.

108. Machado PAL. Direito ambiental brasileiro. São Paulo: Revista dos Tribunais; 1982.

109. Lanphear BP. Childhood lead poisoning prevention-too little, too late. JAMA. 2005;293 (18):2274-6.

Manuscript received on 3 March 2008. Revised version accepted for publication on 23 September 2008. 
RESUMEN La neurotoxicidad adquirida inducida por la exposición prolongada a bajos niveles de plomo tiene una importancia especial en los niños. Una plétora de publicaciones recientes ha demostrado el vínculo directo existente entre la exposición a bajos niveles de

\section{Neurotoxicidad y agresividad desencadenadas por bajos niveles de plomo en niños:} una revisión

Palabras clave plomo y el déficit en el desempeño neuroconductual-cognitivo manifestado desde la infancia hasta el final de la adolescencia. En numerosos estudios, la agresividad y la delincuencia juvenil también se han considerado síntomas de la intoxicación por plomo. Se han identificado y explicado ampliamente varias fuentes ambientales, laborales y domésticas de contaminación por plomo y los riesgos resultantes para la salud, pero aún son numerosos los casos de intoxicación por plomo. Se necesitan urgentes políticas de salud pública para prevenir la intoxicación por plomo de manera de reducir los daños y las pérdidas, tanto individuales como para la sociedad. En este artículo se describen algunas fuentes no sospechadas de contaminación por plomo y se discuten las pérdidas económicas y la violencia urbana posiblemente asociada con este tipo de contaminación. Además, se hace una revisión de las bases moleculares de la neurotoxicidad inducida por plomo, con énfasis en sus efectos sobre el comportamiento social, la delincuencia juvenil y el coeficiente intelectual de los niños y los adolescentes.

Intoxicación por plomo; síndrome de neurotoxicidad; estrés oxidativo; delincuencia juvenil. 